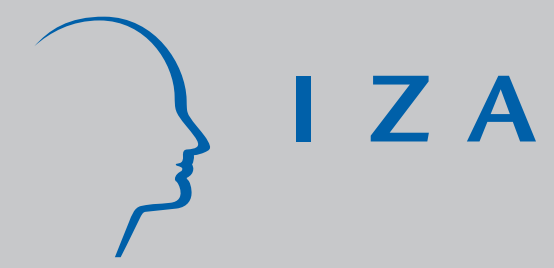

IZA DP No. 1355

Is There a Risk-Return Trade-Off across

Occupations? Evidence from Spain

Luis Diaz-Serrano

J oop Hartog

October 2004 


\title{
Is There a Risk-Return Trade-Off across Occupations? Evidence from Spain
}

\author{
Luis Diaz-Serrano \\ National University of Ireland, Maynooth, \\ CREB, Barcelona and IZA Bonn \\ Joop Hartog \\ FEE-SCHOLAR, University of Amsterdam \\ and IZA Bonn
}

Discussion Paper No. 1355

October 2004

\author{
IZA \\ P.O. Box 7240 \\ 53072 Bonn \\ Germany \\ Phone: +49-228-3894-0 \\ Fax: +49-228-3894-180 \\ Email: iza@iza.org
}

\begin{abstract}
Any opinions expressed here are those of the author(s) and not those of the institute. Research disseminated by IZA may include views on policy, but the institute itself takes no institutional policy positions.
\end{abstract}

The Institute for the Study of Labor (IZA) in Bonn is a local and virtual international research center and a place of communication between science, politics and business. IZA is an independent nonprofit company supported by Deutsche Post World Net. The center is associated with the University of Bonn and offers a stimulating research environment through its research networks, research support, and visitors and doctoral programs. IZA engages in (i) original and internationally competitive research in all fields of labor economics, (ii) development of policy concepts, and (iii) dissemination of research results and concepts to the interested public.

IZA Discussion Papers often represent preliminary work and are circulated to encourage discussion. Citation of such a paper should account for its provisional character. A revised version may be available directly from the author. 
IZA Discussion Paper No. 1355

October 2004

\section{ABSTRACT}

\section{Is There a Risk-Return Trade-Off across Occupations? Evidence from Spain}

We use data from Spain to test for an effect of earnings risk and skewness on individual wages. We carry out separate estimation for men, women, public and private sector employees. In accordance with previous evidence for the US we show the existence of a riskreturn trade-off across occupations in the Spanish labour market. These results are in conformity with preferences of risk-averse individuals with decreasing absolute risk aversion.

JEL Classification: J3, D8

Keywords: risk-aversion, skewness affection, occupational choices, compensating wage differentials

Corresponding author:

Luis Diaz-Serrano

Department of Economics

National University of Ireland

Maynooth, Co. Kildare

Ireland

Email: luis.diaz@may.ie 


\section{Introduction}

In a riskless world, choosing an occupation should be, undoubtedly, an easy task. In such a case, individuals can make their choice just maximizing the earnings across occupations. However, in a risky world like ours, where the fact that workers are averse to fluctuations in their incomes is universally recognised, such a decision becomes much more complicated. Such a fluctuations in earnings is what we call earnings risk.

Economic theory suggests that if these risks are foreseeable, they should be compensated for. In the empirical literature on compensating wage differentials there exist a wide variety of studies analysing the effect of different sources of risk in the job place on wages. However, this literature is mainly focused on injury or fatality risks. As Adam Smith we claim that in a competitive labour market there must exist a way of compensation in those occupations that entail a higher probability of failure (higher variance in earnings) in order to attract sufficient supply. While uncertainty in labour income is accounted for in most theoretical models it has been rarely tested apart from some exceptions in the US.

Additionally, there is also a growing literature that shows the relevance of the skewness of the returns in many economic decisions. For example, Garret and Sobel (1999) and Golec and Tamarking (1998) find evidence that risk-averse individuals playing lottery games and betting in horse races in the US base their participation decision on the skewness of the prize distributions, respectively. Prackash et al. (2003) found empirical evidence from Latin American, US and European capital markets that investors do trade expected return of the portfolio for skewness. DiazSerrano (2004) empirically supports that positive skewness favour homeownership in Germany and Spain. And Hartog and Vijverberg (2002) in the US and Diaz-Serrano, 
Hartog and Nielsen (2004) in Denmark shows that individuals appreciate positively skewed income distributions, and they incorporate this information into their educational choices. In this paper, we empirically test for the Spanish labor market whether risk-averse workers are compensated for earnings risks in their occupational choices, and whether there is a willingness to pay for positive skewness in their incomes.

The remainder of the paper is structured as follows. In section 2 the existing literature in this issue is extensively reviewed. Section 3 presents the theoretical background. In section 4 we describe the empirical framework. In section 5 we

describe the dataset. We carry out the empirical analysis in section 6. And section 7 summarizes and concludes.

\section{Literature review}

In labour economics there is a growing literature dealing with earnings risk and its effects on individuals' behaviour in the labour market. This literature considers three different approaches, the effect of risk on the human capital investment, on the occupational choices, and on the compensating wage differentials.

\subsection{Earnings risk and schooling choices}

Levhari and Weiss (1974) built a two period model with the choice between working or studying during the first period, and stochastic earnings during the second period for those who attended education in the first period. In their theoretical model they obtain that increasing earnings risk reduces the investment in education. Kodde (1986) built on Levhari and Weiss model': in his theoretical model he finds an ambiguous effect, but his empirical estimation suggests increasing demand for 
education with increasing risk. Snow and Warren (1990) found that human capital decreases with increasing risk in its future returns if such investment is an inferior activity and individuals exhibit decreasing risk aversion.

Williams (1979) applied dynamic programming to the education decisions, where production and depreciation of human capital and future wages are all stochastic. He concludes, under conditions, that higher risk in the production of human capital reduces investment in schooling. Belzil and Hansen (2002) and Hogan and Walker (2002) also used the dynamic programming framework, both models find that individuals prefer to stay at school longer with increasing risk in future earnings. The first argue that it is because while being at school they receive non risky parental income, the second attribute this result to the increased value of waiting for a good earnings draw.

The work of Hartog and Diaz-Serrano (2002) constitutes one of the few empirical studies on this issue. They develop a human capital model for optimum schooling length with stochastic earnings and highlight the pivotal role of risk attitudes and the schooling gradient of earnings risk. Their empirical estimation uses Spanish data on high school graduates deciding on attending university education. They find that the basic response to increasing earnings risk is negative but that in households with lower risk aversion, the response will be dampened substantially and may even be reversed to positive.

\subsection{Occupational choices}

Orazem and Mattila (1986) developed an empirical model of occupational choice under uncertainty. They considered the first two moments of the earnings distribution (mean and variance) within various alternative occupations. Their 
empirical results confirm that increasing mean and decreasing variance of the earnings distribution increase the probability of choosing a given occupation. Siow (1984) estimated supply curves assuming uncertainty in the future wages and tenure of the occupational choice by a cohort of entrants into an occupation. This author used a sample of American lawyers. De Meza (1984) also analysed occupational choices under wage uncertainty, this author finds that increasing risk decreases individual's utility.

\subsection{Risk compensation in wages}

This literature starts with King (1974) using aggregated data regressed the variance and the skewness by occupation cells on average earnings, observing a positive effect for variance and negative for skewness in the US labour market. McGoldrick (1995) built on King's work and using US microdata obtained the same results. McGoldrick and Robst (1996) studied the effect of workers mobility on compensating differentials for earnings risk. They observe that workers with high mobility receive smaller compensations for earnings risk, since they show preference for uncertain situations. Also in the context of the US labour market, Feinberg (1981a) estimated significant wage compensation for earnings risk using a 6-years panel. He estimated earnings-risk as the coefficient of variation of individual yearly earnings during the sample period. And Feinberg (1981b) also finds that workers experiencing employment instability in their occupations are compensated for.

Hartog and Vijverberg (2002) were the first to provide a formal modelling on risk compensation in wages. Using US data they estimated structural equations measuring risk and skewness by occupation-education cells, and they observe a positive compensation for risk and a penalty for skewness in wages. Diaz-Serrano, 
Hartog and Nielsen (2003) also estimated positive compensation for risk using Danish panel data. They estimated risk using just education cells and provide new estimates by experimenting with several dynamic measures of earnings risk and skewness. They also found a significant positive effect of the variance and negative for the skewness on wages.

\section{Theoretical background}

As we mention in the previous section, there is a wide number of studies that considers an effect of earnings uncertainty in the educational an occupational choices. However, a little has been said yet about skewness. Tsiang (1974) found theoretical support that risk-averse individuals display preference for skewness, in addition to aversion to dispersion (risk), of the probability distribution of the returns in economic decisions that entail an uncertain outcome. This result suggests that since increasing absolute risk aversion is absurd, decreasing absolute risk aversion requires that individuals appreciate higher moments as e.g. skewness. Other well established theories also emphasize around this finding. For example, prospect theory (Kahneman and Tversky, 1979, 1991) states that the individual's disutility caused by a loss is greater than the utility caused by a gain of the same size, which goes in the same direction as Tsiang's findings. These arguments suggest that if we assume future earnings attached to an occupational/educational choice to be uncertain, both the variance and skewness of earnings, in addition to the mean, should be considered when analyzing how these choices are planned and achieved.

To understand how such a compensation mechanism in wages may arise we follow Hartog and Vijvenberg (2002) and Diaz-Serrano et al. (2004). Assume that a riskaverse individual has to choose between two occupational options that only differ in risk. 
In the riskless alternative, annual earnings are given as $Y_{f}$, generating utility $U\left(Y_{f}\right)$, where $U\left(\right.$ ) is a concave utility function with $U^{\prime}>0, U^{\prime \prime}<0$ and $U^{\prime \prime \prime}>0$ (the latter condition is necessary for declining absolute risk aversion, see Tsiang, 1974 or Hartog and Vijverberg, 2002). In the risky option, income is a single draw for the rest of working life, written as $Y_{r}+\varepsilon$. Equal expected lifetime utility requires

$$
\int_{0}^{T} U\left(Y_{f}\right) e^{-\rho t} d t=E \int_{0}^{T} U\left(Y_{r}+\varepsilon\right) e^{-\rho t} d t
$$

where $\mathrm{T}$ is the length of working life and $\rho$ the time discount rate. We can write the lefthand side as

$$
\int_{0}^{T} U\left(Y_{f}\right) e^{-\rho t} d t=\frac{1}{\rho}\left(1-e^{-\rho T}\right) U\left(Y_{f}\right)
$$

For the stochastic term on the right-hand side we apply a third-order Taylor expansion around the expected value $Y_{r}$, one order up from Pratt's original contribution (Pratt, 1964), to

$$
\int_{0}^{T} U\left(Y_{r}+\varepsilon\right) e^{-\rho t} d t=\frac{1}{\rho}\left(1-e^{-\rho T}\right)\left[U\left(Y_{r}\right)+\frac{1}{2} U{ }^{\prime \prime}\left(Y_{r}\right) \sigma_{p}^{2}+\frac{1}{6} U^{\prime \prime}\left(Y_{r}\right) \kappa_{p}^{3}\right]
$$

where $\sigma_{\mathrm{p}}^{2}$ is the second moment (risk) and $\kappa_{\mathrm{p}}^{2}$ is the third moment (skewness) of $\varepsilon$ around the expected value zero. Equating (2) and (3) and rewriting a little, after applying a first-order Taylor expansion around $Y_{r}$ for (2), we get

$$
\frac{Y_{r}-Y_{f}}{Y_{r}}=-\frac{1}{2} \frac{\sigma_{p}^{2}}{Y_{r}^{2}} \frac{U^{\prime \prime}}{U^{\prime}} Y_{r}-\frac{1}{6} \frac{\kappa_{p}^{3}}{Y_{r}^{3}} \frac{U^{\prime \prime \prime}}{U^{\prime \prime}} Y_{r} \frac{U^{\prime \prime}}{U^{\prime}} Y_{r}=\frac{1}{2} \frac{\sigma_{p}^{2}}{Y_{r}^{2}} V_{r}-\frac{1}{6} \frac{\kappa_{p}^{3}}{Y_{r}^{3}} V_{s} V_{r}
$$

where $V_{r}$ is Arrow-Pratt's relative risk aversion and $V_{s}$ is the similar definition for relative skewness affection (we call it affection, because individuals like skewness; see Hartog and Vijverberg, 2002). With $V_{r}$ and $V_{s}$ positive by definition, we note from (4) that 
individuals only enter an occupation if the permanent effect from an unknown occupational outcome is matched by a positive premium for the risk (variance), while they allow an earnings drop for skewness.

\section{Empirical framework}

Assume that earnings of an individual can be expressed as follows

$$
Y_{i s j}=Y_{s} \eta_{i j}
$$

where $Y_{i s j}$ are the observed earnings of individual $i$ with education $S$ in occupation $j$, $Y_{s}=\mu_{S} Y_{0}$ are the expected earnings of an individual with education level $S$, with $Y_{0}=\exp (X \beta)$, and $\eta_{i j}=\exp \left(u_{i j}\right)$ is a term picking up specific effects on earnings of individuals' occupation. This specification allows individuals with the same schooling to earn different wages. Appling logarithms in both sides of (5) we get

$$
\log Y_{i j}=\log \mu_{s}+X_{i} \beta+u_{i j}
$$

where $X$ are the observable determinants of $Y_{i j}$, $\log \mu_{s}$ is the fixed effect of education on wages, and $u_{i j}$ is the effect on wages of occupation $j$ for individual $i$. Expression (6) provides the familiar Mincer mark-up model. If wages include a compensation for risk in labour earnings, $u_{i j}$ can be decomposed as follows

$$
u_{i j}=\lambda_{j}+\alpha \sigma_{j}^{2}+\gamma \kappa_{j}^{3}+u_{i}
$$

where $\lambda_{j}$ are the occupation fixed-effects, $\sigma_{j}^{2}$ is the variance of earnings within

occupations, $\kappa_{j}^{3}$ is the skewness, and $u_{i}$ is a random term normally distributed with 0 mean and constant variance across individuals. By substituting (7) in (6), the complete specification of individuals' earnings can be expressed as 


$$
\log Y_{i}=\log \mu_{s}+\lambda_{j}+X_{i} \beta+\alpha \sigma_{j}^{2}+\gamma \kappa_{j}^{3}+u_{i}
$$

The existence of a risk compensation requires $\alpha>0$, whereas the so called "skewness affection" that entails a penalty in wages requires $\gamma<0$. We take as suitable

measures of $\sigma_{j}^{2}$ (hereafter $R_{j}$ ) and $\kappa_{j}^{3}$ (hereafter $K_{j}$ ) the variance and the skewness of the observed earnings by occupations cells, respectively.

We decompose earnings according to the source of variation, i.e. systematic and unsystematic component. Systematic fluctuations in earnings are caused by supply variables (e.g. human capital), which are usually known by individuals, and therefore, have nothing to do with risk. However, unsystematic variations in earnings catch variations which are unknown by individuals when they have to make their choice of education and ensuing occupation. They reflect indeed the risk to the individual: their as yet unknown abilities, suitability for her job, and hence relative position in the occupations' earnings distribution. They also reflect demand factors (e.g. business cycle or shocks in output demand) and they are expected to generate compensating wage differentials. Hence, suitable measures of risk and skewness in wages require that systematic variation in wages shall be purged from observed earnings, since otherwise the true relationship between risk and wages might be obscured.

We use a two-step method to test for risk compensation in the earnings equation (8). Firstly, we estimate equation (6), where we assume that $\log \mu_{s}+X_{i} \beta$ collects the systematic variation in earnings, and hence the estimated residuals are used to calculate R and K by occupations as follows 


$$
\begin{aligned}
& R_{j}=E_{j}\left\{\hat{\eta}_{i j}-E_{j}\left(\hat{\eta}_{i j}\right)\right\}^{2} \\
& K_{j}=E_{j}\left\{\hat{\eta}_{i j}-E_{j}\left(\hat{\eta}_{i j}\right)\right\}^{3}
\end{aligned}
$$

where $\hat{\eta}_{i j}=\exp \left(\hat{u}_{i j}\right)$ and the exponential transformation on the estimated residuals $\hat{u}_{i j}$ is applied in order to transfer unsystematic earnings back to the money metric. And secondly, the estimates of $R_{j}$ and $K_{j}$ obtained in the first round are plugged in the wage equation (8). One might expect the occupation fixed-effects $\lambda_{j}$ in expression (7) to be known by individuals, and hence, we calculate risk and skewness around the occupational mean. However, we cannot include the occupation fixed effects in the second round, as we have already fixed $\mathrm{R}$ and $\mathrm{K}$ for given occupation. The interpretation of $\alpha$ in equation (8) is the amount of extra wages that an individual requires for an additional unit of risk. By analogy to $\alpha, \gamma$ is the amount of wage that an individual is willing to pay for an additional unit of positive skewness.

\section{Data description}

To carry out the empirical analysis we use a sample of the Family Budget Survey 1990 (Encuesta de Presupuestos Familiares 1990 - EPF/90). The EPF/90 is a nationwide representative survey, which is designed with the aim of updating the list

of goods and services acquired by Spanish households. It is used in the estimation of private consumption, and the elaboration of the Consumption Prices Index, and also to reveal the expenditures and the earnings of the Spanish households. The survey also provides information about individual annual earnings. In the EPF/90, 21,150 households are surveyed. The file on individual information has a sample size of 78,273 observations, among whose 18,132 are wage earners working in either the private or the public sector. In our empirical estimation of the reduced form wage 
equations we select salaried males and females, aged between 18 and 65, and working in either the public or the private sector. This selection provides a sample of salaried workers of 17,919 individuals. Table 1 provides descriptive sample statistics of some selected variables used in our empirical estimations.

Insert table 1 here

\section{Empirical results}

In this section we present the empirical results derived from the OLS estimates of the wage equation (8). We use as endogenous variable the workers' gross yearly wages ${ }^{1}$. We run regressions for the full sample of salaried workers, and also separate estimations for males and females, and for public and private sector employees. We also use the standard methods to control for selectivity bias, the well-known Heckman's (1976) method for the females’ wage equation and Lee $(1983)^{2}$ for publicprivate sector employees’ wage equations.

In table 2 we report the results of the choice equation for female participation in the labour market used to correct for selectivity bias in female wages. Women who

\footnotetext{
${ }^{1}$ The EPF/90 provides net annual earnings, however, we proxy gross earnings by transforming from net earnings using the tax rates for different wage levels and family sizes and the corresponding social security payments.

${ }^{2}$ Assume that wages in public and the private sector are determined by the following linear relationship $\log W_{k, i}=\alpha_{k}+\beta_{k} X_{i}+u_{k, i}$, where the subscript $k$ denotes public or private If we define $Y_{k i}$ as the unobserved propensity of individual $i$ to work in sector $k$ (public or private), this unobserved propensity can be expressed as a linear function of the individual's and the demand's observed characteristics as $Y_{k i}=\delta_{k}+\gamma_{k} Z_{i}+\varepsilon_{k i}$. Taking expectations on wages condition to the choice of the sector $k$ we get $E\left(\log W_{i} \mid k\right)=\alpha_{k}+\beta_{k} X_{i}+E\left(u_{i} \mid k\right)$. Selectivity exists if $E\left(u_{i} \mid k\right) \neq 0$, i.e. when assignment to a given sector is not random. Defining the probability of being employed in sector $\mathrm{k}$ as $P_{k i}=\exp \left(\delta_{k}+\gamma_{k} Z_{i}\right) / \sum \exp \left(\delta_{k}+\gamma_{k} Z_{i}\right)$, then the conditional expectation on the right hand side can be expressed as $E\left(u_{i} \mid k\right)=\pi_{k} \lambda_{i k}$, where $\lambda_{i k}=\phi\left\{\Phi^{-1}\left(P_{i k}\right)\right\} / P_{i k}$, and $\phi$ and $\Phi^{-1}$ denote the standard univariate normal density and the inverse normal distribution function, respectively. Hence, the full specification with selectivity bias correction now reads as $\log W_{i k}=\alpha_{k}+\beta_{k} X_{i}+\phi_{k} \lambda_{i k}+\varepsilon_{i k}$.
} 
are more educated, married, and living in urban areas are more likely to participate in the labour market, whereas the opposite holds for older women and women with children. Table 3 shows the results of the choice equation between public and private employees used to correct for selectivity bias in the public-private sector wage equations. More educated, younger, married, urban and more skilled workers are more likely to be employed in the private sector, whereas men and workers with children are more likely to be employees in the public sector.

Insert table 2 here

Insert table 3 here

Table 4 shows the results of the estimation of equation (6) for the selected workforce groups. As variables expected to generate systematic variations in earnings we consider years of schooling, a cubic polynomial on potential years of experience, and dummies for gender, region and urbanisation. Explanatory variables are highly significant (at $1 \%$ level or better), and behave according to expectations. Returns to schooling are greater for women than for men, whereas this result is reversed for returns to experience. Wages also tend to be higher in urban areas for all selected workforce groups. Differences in the returns to schooling and to experience between public and private employees are fairly modest, whereas wage differentials by gender and urbanizations are significantly smaller in the public than in the private sector. The selectivity bias correction term is very significant in the split public-private sector wage equations. However, although the choice model for female participation has reported significant effects for a number of exogenous variables, surprisingly the correction term has turned out to be immaterial. Differences in the estimated parameters between corrected and uncorrected specification are negligible. 
Insert table 4 here

In table 5 we show summary statistics of the estimations of $R_{j}$ (risk) and $K_{j}$ (skewness). A first look allows us to observe that risk and skewness possess enough variability to seek for effects in the wage equation (8). Risk and skewness tend to be greater for men and private sector employees than for women and public workers, increasing with age and decreasing with education. The Commerce, Agriculture, Construction and Transport industries offer riskier wage distributions than the manufacturing and banking industries. In general, occupations that require a greater degree of skills (managers and qualified workers) also offer riskier wages.

\section{Insert table 5 here}

We present our key results on risk compensation in table 6, for the sake of simplicity we just show the results for the effects of schooling, risk and skewness. We use three different specifications for equation (8): excluding $\mathrm{R}$ and $\mathrm{K}$, excluding $\mathrm{K}$ and including $\mathrm{R}$ and $\mathrm{K}$. In all these specifications we use the coefficient associated to the returns to schooling to evaluate the sensitivity or potential omitted-variable bias of this coefficient to the omission of risk and skewness. Our results allow us to reject the existence of bias due to risk omission in the rate of returns to schooling. The complete specification of equation (8) also considers a cubic polynomial on years of experience, and additive dummies for gender, family status, geographical location, industry, and some broad occupational-skill groups. The latter set of dummies allows us to capture the fixed-effect of these skill groups.

Insert table 6 here 
Our results allow us to conclude that risk-averse workers are compensated for earnings risk, i.e. significant and positive sign for $\mathrm{R}$, and penalised for positive skewness, i.e. significant and negative for K. This result persists across alternative samples and specifications. It is also worth noting that the risk coefficients have shown a great sensitivity to the inclusion/omission of skewness. Economic significance of the coefficients is assessed by the elasticities in italic letters. These results suggest that risk compensation and skewness penalty are greater for women than for men. For men, with a $10 \%$ increase in risk and skewness, wages are raised about $0.25 \%$ and penalized about $0.1 \%$. For women, these numbers are $0.36 \%$ and $1 \%$, respectively. Between public and private employees we also find marked differentials in the risk compensation, a $10 \%$ increase in risk raises wages about $0.86 \%$ for public employees, whereas for their counterparts in the private sector wages increase only about $0.18 \%$. An equivalent increment in skewness depresses wages about $0.9 \%$ and $0.12 \%$ for public and private employees, respectively.

\section{Summary and concluding remarks}

In this study we report the existence of compensating wage differentials for earnings risk in the Spanish labour market. The existence of such a risk compensation for different workforce groups reveals that the finding is quite robust. Our results are also consistent with previous evidence for the US and Denmark. From these results we conclude that the risk-return trade-off across occupations is well established and is consistent with the preferences of risk/averse agents with declining absolute risk aversion. Our results also suggest that women and public sector employees are more risk-averse than men and their counterparts in the private sector. These results also fit within previous evidence for the US that shows increasing probability to be employed 
in the public sector with increasing individual risk-aversion (see Belante and Link, 1981) and in with the evidence that women are more risk averse than men and hence, require higher compensation for risk (see McGoldrick, 1995 and Schubert et al., 1999).

We recognize that as in Hartog and Vijverberg (2002) and Diaz-Serrano, Hartog and Nielsen (2004), structural estimates and measures catching the dynamic nature of risk would provide a more suitable framework. However, the required long and rich panel data sets are rarely available for most of the countries. Hence, further research in this line is encouraged. 


\section{References}

Bellante, D. and A.N. Link (1981): “Are public sector workers more risk averse than private sector workers?”, Industrial Labor Relations Review 34, pp. 408-412.

Belzil, C. and J. Hansen (2002): “Earnings dispersion, risk aversion and education” IZA Discussion Paper \#513, IZA, Bonn.

Christiansen, C. and H.S. Nielsen (2002): “The educational asset market: a finance perspective on human capital investment”, ASB Working Paper \#02-10, ASB, Aarhus.

De Meza, D. (1984): "Wage uncertainty, expected utility and occupational choice”, International Economic Review 25, pp. 757-762.

Diaz-Serrano, L., J. Hartog and H.S. Nielsen (2003): “Compensating wage differentials for schooling risk in Denmark”, IZA discussion paper \#963, IZA, Bonn.

Diaz-Serrano, L. (2004), "Labor income uncertainty, skewnes and homeownership: a panel data study for Germany and Spain”, IZA discussion paper \#1008, IZA, Bonn.

Feinberg, R. (1981a): “Earnings-risk as a compensating differential”, Southern Economic Journal 48, pp. 156-163.

Feinberg, R. (1981b): “Employment instability, earnings, and market structure”, Applied Economics 13, pp. 257-265.

Garrett T.A. and R.S. Sobel (1999): “Gamblers favor skewness, not risk: further evidence from the United States’ Lottery games”, Economics Letters 63, pp. 85-90.

Golec, J. and M. Tamarking (1998): “Bettors love skewness, not risk, at the horse track”, Journal of Political Economy 106, pp. 205-225.

Hartog, J. and L. Diaz-Serrano (2002): “Earnings risk and demand for higher education: a cross-section test for Spain”, IZA Discussion Paper \#641, IZA, Bonn.

Hartog, J. and W. Vijverberg (2002): “Do wages really compensate for risk aversion and 
skewness affection”, IZA discussion papers \#426, IZA, Bonn.

Hartog, J., E.J.S. Plug, L. Diaz-Serrano and A.J.C. Vieira (2003): "Risk compensation in wages: a replication”, Empirical Economics 28, pp. 639-647.

Heckman, J.J. (1976): “The common structure of statistical models of truncation, sample selection, and limited dependent variables and a simple estimator for such models”, Annals of Economic and Social Measurement 5, pp. 475-492.

Hogan, V. and I. Walker (2001): "Education choice under uncertainty”, Working Paper UCD, Dublin.

Kahneman D. and A. Tversky (1979): "Prospect theory: an analysis of decision under risk”, Econometrica 47, pp. 263-291.

Kahneman D. and A. Tversky (1991): "Loss aversion in riskless choice: a referencedependent model”, Quarterly Journal of Economics 106, pp. 1039-1061.

King, A.G. (1974): “Occupational choice, risk aversion, and wealth”, Industrial and Labor Relations Review 27, pp. 586-96.

Kodde, D.A. (1986): "Uncertainty and the demand for education”, Review of Economics and Statistics 68, pp. 460-67.

Koenker, R. and R. Bassett (1978): “Regression quantiles”, Econometrica 46, pp. 33-50.

Lee, L. (1983): “Generalised econometric models with selectivity”, Econometrica 51, pp. 507-512.

Levhari, D. and Y. Weiss (1974): “The effect of risk on the investment in human capital”, American Economic Review 64, pp. 950-63.

McGoldrick, K. (1995): “Do women receive compensating wages for earnings uncertainty?”, Southern Economic Journal 62, pp. 210-222.

McGoldrick, K. and J. Robst (1996): “The effect of worker mobility on compensating wages for earnings risk”, Applied Economics 28, pp. 221-232. 
Orazem, P.F. and J.P. Mattila (1986): “Occupational entry and uncertainty: males leaving high school”, Review of Economics and Statistics 67, pp. 265-273.

Prakash, A. J., C.H. Chang and T.E. Pactwa (2003): "Selecting a portfolio with skewness: recent evidence from US, European, and Latin American equity markets”, Journal of Banking and Finance 27, pp. 1375-1390.

Schubert, R., M. Brown, M. Gysler; H.W. Brachinger (1999): "Financial DecisionMaking: Are Women Really More Risk-Averse?”, American Economic Review 89, pp. 381-385.

Siow, A. (1984): “Occupational choice under uncertainty”, Econometrica 52, pp. 631-645.

Snow, A. and R.S. Warren (1990): “Human capital investment and labor supply under uncertainty”, International Economic Review 31, pp. 195-206.

Tsiang, S.C. (1974): “The rationale of the mean-standard deviation analysis, skewness preference, and the demand for money”, American Economic Review 64, pp. 354-371.

Williams, J. (1979): "Uncertainty and the accumulation of human capital over the lifecycle”, Journal of Business 52, pp. 521-48. 
Table 1: Sample descriptive statistics

\begin{tabular}{|c|c|c|c|c|c|c|c|c|c|c|}
\hline & \multicolumn{2}{|c|}{ Full sample } & \multicolumn{2}{|c|}{ Women } & \multicolumn{2}{|c|}{ Men } & \multicolumn{2}{|c|}{ Public sector } & \multicolumn{2}{|c|}{ Private sector } \\
\hline & Mean & STD & Mean & STD & Mean & STD & Mean & STD & Mean & STD \\
\hline Age & 37,14 & 12,09 & 34,03 & 11,40 & 38,54 & 12,14 & 39,10 & 11,48 & 36,46 & 12,23 \\
\hline Women & 0,31 & 0,46 & & & & & 0,38 & 0,49 & 0,29 & 0,45 \\
\hline Married & 0,36 & 0,48 & 0,31 & 0,46 & 0,38 & 0,48 & 0,41 & 0,49 & 0,34 & 0,47 \\
\hline Household size & 4,14 & 1,54 & 4,02 & 1,57 & 4,19 & 1,52 & 3,93 & 1,51 & 4,22 & 1,54 \\
\hline \# of children & 0,57 & 0,50 & 0,52 & 0,50 & 0,59 & 0,49 & 0,55 & 0,50 & 0,58 & 0,49 \\
\hline Years of schooling & 8,39 & 4,29 & 9,21 & 4,40 & 8,03 & 4,19 & 10,78 & 4,65 & 7,56 & 3,83 \\
\hline Log(yearly wages) & 13,87 & 0,83 & 13,55 & 0,89 & 14,01 & 0,75 & 14,19 & 0,74 & 13,76 & 0,83 \\
\hline \multicolumn{11}{|l|}{ Dummies industry } \\
\hline Agriculture & 0,08 & 0,26 & 0,05 & 0,21 & 0,09 & 0,28 & 0,01 & 0,12 & 0,10 & 0,30 \\
\hline Energy & 0,02 & 0,14 & 0,00 & 0,07 & 0,03 & 0,16 & 0,02 & 0,14 & 0,02 & 0,14 \\
\hline Chemical & 0,03 & 0,17 & 0,01 & 0,11 & 0,04 & 0,20 & 0,02 & 0,13 & 0,04 & 0,19 \\
\hline Mechanics & 0,08 & 0,26 & 0,02 & 0,14 & 0,10 & 0,30 & 0,02 & 0,13 & 0,10 & 0,29 \\
\hline Other manufactures & 0,13 & 0,33 & 0,13 & 0,34 & 0,12 & 0,33 & 0,01 & 0,11 & 0,16 & 0,37 \\
\hline Construction & 0,10 & 0,30 & 0,01 & 0,11 & 0,14 & 0,35 & 0,02 & 0,14 & 0,13 & 0,34 \\
\hline Commerce & 0,16 & 0,37 & 0,19 & 0,39 & 0,15 & 0,35 & 0,02 & 0,12 & 0,21 & 0,41 \\
\hline Transport & 0,06 & 0,23 & 0,03 & 0,16 & 0,07 & 0,26 & 0,08 & 0,28 & 0,05 & 0,22 \\
\hline Banking & 0,05 & 0,22 & 0,05 & 0,21 & 0,05 & 0,22 & 0,01 & 0,10 & 0,06 & 0,24 \\
\hline Other services & 0,30 & 0,46 & 0,51 & 0,50 & 0,21 & 0,41 & 0,79 & 0,40 & 0,13 & 0,34 \\
\hline \multicolumn{11}{|l|}{ Dummies occupation } \\
\hline Managerial & 0,01 & 0,10 & 0,00 & 0,05 & 0,01 & 0,12 & 0,01 & 0,10 & 0,01 & 0,10 \\
\hline Professionals & 0,09 & 0,29 & 0,13 & 0,33 & 0,08 & 0,27 & 0,23 & 0,42 & 0,04 & 0,20 \\
\hline Scientists & 0,07 & 0,26 & 0,11 & 0,31 & 0,05 & 0,23 & 0,12 & 0,33 & 0,05 & 0,22 \\
\hline Technicians & 0,13 & 0,33 & 0,20 & 0,40 & 0,09 & 0,29 & 0,19 & 0,39 & 0,10 & 0,31 \\
\hline Clerical & 0,21 & 0,41 & 0,37 & 0,48 & 0,14 & 0,34 & 0,16 & 0,37 & 0,23 & 0,42 \\
\hline Qualified workers & 0,06 & 0,24 & 0,00 & 0,07 & 0,08 & 0,28 & 0,04 & 0,18 & 0,07 & 0,25 \\
\hline Clerical & 0,08 & 0,28 & 0,01 & 0,11 & 0,12 & 0,32 & 0,05 & 0,22 & 0,10 & 0,30 \\
\hline Manual workers & 0,33 & 0,47 & 0,18 & 0,38 & 0,39 & 0,49 & 0,14 & 0,35 & 0,39 & 0,49 \\
\hline Other & 0,02 & 0,14 & 0,00 & 0,07 & 0,03 & 0,16 & 0,06 & 0,24 & 0,01 & 0,08 \\
\hline Public workers & 0,26 & 0,44 & 0,32 & 0,46 & 0,23 & 0,42 & & & & \\
\hline \multicolumn{11}{|l|}{ Dummies location } \\
\hline Urban area & 0,58 & 0,49 & 0,62 & 0,49 & 0,56 & 0,50 & 0,70 & 0,46 & 0,53 & 0,50 \\
\hline Region 1 & 0,40 & 0,49 & 0,39 & 0,49 & 0,40 & 0,49 & 0,40 & 0,49 & 0,40 & 0,49 \\
\hline Region 2 & 0,37 & 0,48 & 0,37 & 0,48 & 0,37 & 0,48 & 0,40 & 0,49 & 0,36 & 0,48 \\
\hline Region 3 & 0,23 & 0,42 & 0,24 & 0,43 & 0,23 & 0,42 & 0,20 & 0,40 & 0,24 & 0,43 \\
\hline Sample size & \multicolumn{2}{|c|}{18132} & \multicolumn{2}{|c|}{5620} & \multicolumn{2}{|c|}{12512} & \multicolumn{2}{|c|}{4675} & \multicolumn{2}{|c|}{13457} \\
\hline
\end{tabular}


Table 2: Probit estimates for female participation

\begin{tabular}{lcr}
\hline \hline & Coefficient & Z-stat \\
\hline Constant & -3.6399 & $(-18.6)$ \\
Primary education & 0.1565 & $(2.5)$ \\
Secondary education & 0.3684 & $(8.4)$ \\
Higher education & 1.0198 & $(4.3)$ \\
Age & 0.1098 & $(8.7)$ \\
Age square & -0.0016 & $(-6.8)$ \\
Children & -0.2909 & $(-4.7)$ \\
Married & 0.3725 & $(7.1)$ \\
Number of wage earners & 0.5089 & $(3.8)$ \\
Urban area & 0.1374 & $(4.2)$ \\
\hline 0 - Non-participant & 15569 & \\
1 - Participant & 5620 & \\
\hline Sample size & 21189 &
\end{tabular}

Notes: Endogenous variable is female participation.

Estimates include dummies for region. 
Table 3: Probit estimates for public-private sector choice

\begin{tabular}{lcr}
\hline \hline & Coefficient & Z-stat \\
\hline Intercept & -4.1242 & $(-16.1)$ \\
Primary education & 0.3698 & $(4.6)$ \\
Secondary education & 0.9197 & $(10.1)$ \\
Higher education & 1.6174 & $(16.0)$ \\
Actually studying & 0.4602 & $(6.5)$ \\
Age & 0.0998 & $(7.9)$ \\
Age square & -0.0008 & $(-7.3)$ \\
Female & 0.2351 & $(7.4)$ \\
Children & -0.1505 & $(-3.4)$ \\
Married & 0.1630 & $(3.7)$ \\
Urban & 0.2127 & $(7.1)$ \\
Region 1 & 0.0728 & $(1.6)$ \\
Region 3 & 13417 & \\
Scientists & -0.4938 & $(-9.7)$ \\
Professionals & 0.5552 & $(6.1)$ \\
Operators & 0.1760 & $(2.1)$ \\
Administrative & 0.1258 & $(1.6)$ \\
White-collars & -0.3535 & $(-4.8)$ \\
Blue-collars & -0.6774 & $(-7.4)$ \\
\hline Public sector & -0.9382 & $(-13.0)$ \\
Private sector & 4675 & \\
\hline Sample size & & \\
\hline Note: Endogenos & & \\
\hline
\end{tabular}

Note: Endogenous variable is working in the private sector. 
Table 4: OLS and two-step estimates of equation (2) used to purge systematic earnings.

\begin{tabular}{|c|c|c|c|c|c|c|}
\hline & Full sample & Males & Females & Females $^{1}$ & Public $^{2}$ & Private $^{2}$ \\
\hline Constant & $\begin{array}{r}12.2383 \\
(397.8)\end{array}$ & $\begin{array}{r}12.1515 \\
(334.6)\end{array}$ & $\begin{array}{r}11.6686 \\
(212.2)\end{array}$ & $\begin{array}{r}11.6906 \\
(103.7)\end{array}$ & $\begin{array}{r}13.0405 \\
(110.1)\end{array}$ & $\begin{array}{r}12.4335 \\
(328.0)\end{array}$ \\
\hline Schooling & $\begin{array}{r}0.0969 \\
(71.1)\end{array}$ & $\begin{array}{r}0.0849 \\
(57.8)\end{array}$ & $\begin{array}{r}0.1182 \\
(44.3)\end{array}$ & $\begin{array}{r}0.1198 \\
(41.1)\end{array}$ & $\begin{array}{r}0.0658 \\
(17.5)\end{array}$ & $\begin{array}{r}0.0675 \\
(24.8)\end{array}$ \\
\hline Exp. & $\begin{array}{r}0.0757 \\
(18.2)\end{array}$ & $\begin{array}{r}0.0937 \\
(18.9)\end{array}$ & $\begin{array}{r}0.0843 \\
(11.3)\end{array}$ & $\begin{array}{r}0.0835 \\
(11.1)\end{array}$ & $\begin{array}{r}0.0736 \\
(10.4)\end{array}$ & $\begin{array}{r}0.0613 \\
(12.3)\end{array}$ \\
\hline Exp. square & $\begin{array}{r}-0.0014 \\
(-7.2)\end{array}$ & $\begin{array}{r}-0.0018 \\
(-8.1)\end{array}$ & $\begin{array}{r}-0.0025 \\
(-6.7)\end{array}$ & $\begin{array}{r}-0.0025 \\
(-6.7)\end{array}$ & $\begin{array}{r}-0.0017 \\
(-7.4)\end{array}$ & $\begin{array}{r}-0.0011 \\
(-4.8)\end{array}$ \\
\hline Exp. cube & $\begin{array}{r}6.4 \cdot 10^{-6} \\
(2.5)\end{array}$ & $\begin{array}{r}8.9 \cdot 10^{-6} \\
(3.1)\end{array}$ & $\begin{array}{r}2.6 \cdot 10^{-5} \\
(4.9)\end{array}$ & $\begin{array}{r}2.5 \cdot 10^{-5} \\
(4.9)\end{array}$ & $\begin{array}{r}1.4 \cdot 10^{-5} \\
(3.4)\end{array}$ & $\begin{array}{r}2.6 \cdot 10^{-6} \\
(0.8)\end{array}$ \\
\hline Female & $\begin{array}{r}-0.4507 \\
(-41.2)\end{array}$ & & & & $\begin{array}{r}-0.3178 \\
(-17.9)\end{array}$ & $\begin{array}{r}-0.5673 \\
(-42.4)\end{array}$ \\
\hline Urban & $\begin{array}{r}0.1319 \\
(12.6)\end{array}$ & $\begin{array}{r}0.1374 \\
(11.9)\end{array}$ & $\begin{array}{r}0.1274 \\
(6.1)\end{array}$ & $\begin{array}{r}0.1293 \\
(6.2)\end{array}$ & $\begin{array}{r}0.1263 \\
(6.2)\end{array}$ & $\begin{array}{r}0.1268 \\
(10.4)\end{array}$ \\
\hline Region 1 & $\begin{array}{r}-0.0937 \\
(-8.2)\end{array}$ & $\begin{array}{r}-0.0963 \\
(-7.6)\end{array}$ & $\begin{array}{r}-0.0872 \\
(-3.8)\end{array}$ & $\begin{array}{r}-0.0860 \\
(-3.7)\end{array}$ & $\begin{array}{r}-0.0829 \\
(-4.2)\end{array}$ & $\begin{array}{r}-0.1006 \\
(-7.4)\end{array}$ \\
\hline Region 3 & $\begin{array}{r}0.1044 \\
(7.9)\end{array}$ & $\begin{array}{r}0.1105 \\
(7.5)\end{array}$ & $\begin{array}{r}0.1052 \\
(4.1)\end{array}$ & $\begin{array}{r}0.1079 \\
(4.2)\end{array}$ & $\begin{array}{r}0.1147 \\
(4.6)\end{array}$ & $\begin{array}{r}0.2034 \\
(12.2)\end{array}$ \\
\hline Correction term & & & & $\begin{array}{r}-0.0403 \\
(-1.3) \\
\end{array}$ & $\begin{array}{r}-0.2856 \\
(-7.1) \\
\end{array}$ & $\begin{array}{r}0.3992 \\
(9.9) \\
\end{array}$ \\
\hline Sample size & 17919 & 12512 & 5251 & 5251 & 4675 & 13457 \\
\hline
\end{tabular}

Notes: (1) Heckman's selectivity correction

(2) Lee's selectivity correction 
Table 5: Summary statistics for estimated R (risk) and K (skewness).

\begin{tabular}{|c|c|c|c|c|}
\hline & \multicolumn{2}{|c|}{ Risk } & \multicolumn{2}{|c|}{ Skewness } \\
\hline & Mean & STD & Mean & STD \\
\hline Total & 0.631 & 0.867 & 3.502 & 3.140 \\
\hline \multicolumn{5}{|l|}{ Industry } \\
\hline Agriculture & 0.804 & 0.897 & 5.608 & 1.421 \\
\hline Energy & 0.561 & 0.333 & 2.681 & 1.838 \\
\hline Chemical & 0.588 & 0.887 & 2.255 & 1.999 \\
\hline Mechanics & 0.500 & 0.935 & 2.653 & 1.952 \\
\hline Other manufactures & 0.660 & 0.774 & 3.493 & 3.331 \\
\hline Construction & 0.801 & 0.424 & 8.096 & 4.493 \\
\hline Commerce & 0.809 & 1.506 & 2.976 & 1.810 \\
\hline Transport & 0.791 & 0.549 & 4.100 & 2.959 \\
\hline Banking & 0.492 & 0.694 & 2.529 & 1.811 \\
\hline Other services & 0.457 & 0.505 & 2.143 & 2.070 \\
\hline \multicolumn{5}{|l|}{ Education } \\
\hline Incomplete primary & 0.666 & 0.572 & 4.973 & 3.738 \\
\hline Primary & 0.678 & 0.835 & 3.955 & 3.421 \\
\hline Secondary & 0.602 & 1.057 & 2.971 & 2.247 \\
\hline University & 0.484 & 0.816 & 1.690 & 1.361 \\
\hline \multicolumn{5}{|l|}{ Job level } \\
\hline Managerial & 0.782 & 0.463 & 1.380 & 0.974 \\
\hline Professionals & 0.421 & 0.094 & 1.284 & 0.453 \\
\hline Scientists & 0.600 & 0.346 & 1.907 & 1.750 \\
\hline Technicians & 0.419 & 0.024 & 3.081 & 1.230 \\
\hline Clerical & 0.597 & 0.663 & 2.601 & 2.051 \\
\hline Qualified workers & 1.813 & 2.807 & 5.840 & 2.683 \\
\hline Clerical & 0.455 & 0.117 & 3.280 & 1.516 \\
\hline Manual workers & 0.649 & 0.482 & 5.046 & 4.215 \\
\hline Other & 0.240 & 0.151 & 1.153 & 0.487 \\
\hline \multicolumn{5}{|l|}{ Age } \\
\hline 18 to 25 & 0.600 & 0.541 & 3.424 & 3.009 \\
\hline 25 to 35 & 0.624 & 0.846 & 3.386 & 3.045 \\
\hline 35 to 45 & 0.645 & 1.003 & 3.461 & 3.157 \\
\hline 45 to 55 & 0.643 & 0.898 & 3.751 & 3.376 \\
\hline 55 to 65 & 0.665 & 1.062 & 3.699 & 3.213 \\
\hline \multicolumn{5}{|l|}{ Sector } \\
\hline Private & 0.685 & 0.952 & 3.853 & 3.281 \\
\hline Public & 0.476 & 0.525 & 2.492 & 2.427 \\
\hline \multicolumn{5}{|l|}{ Gender } \\
\hline Men & 0.676 & 0.974 & 3.993 & 3.418 \\
\hline Women & 0.532 & 0.550 & 2.409 & 2.019 \\
\hline
\end{tabular}


Table 6: Estimation of returns to schooling, returns to risk and skewness penalty for several workforce groups ${ }^{1}$. (t-statistics in parenthesis)

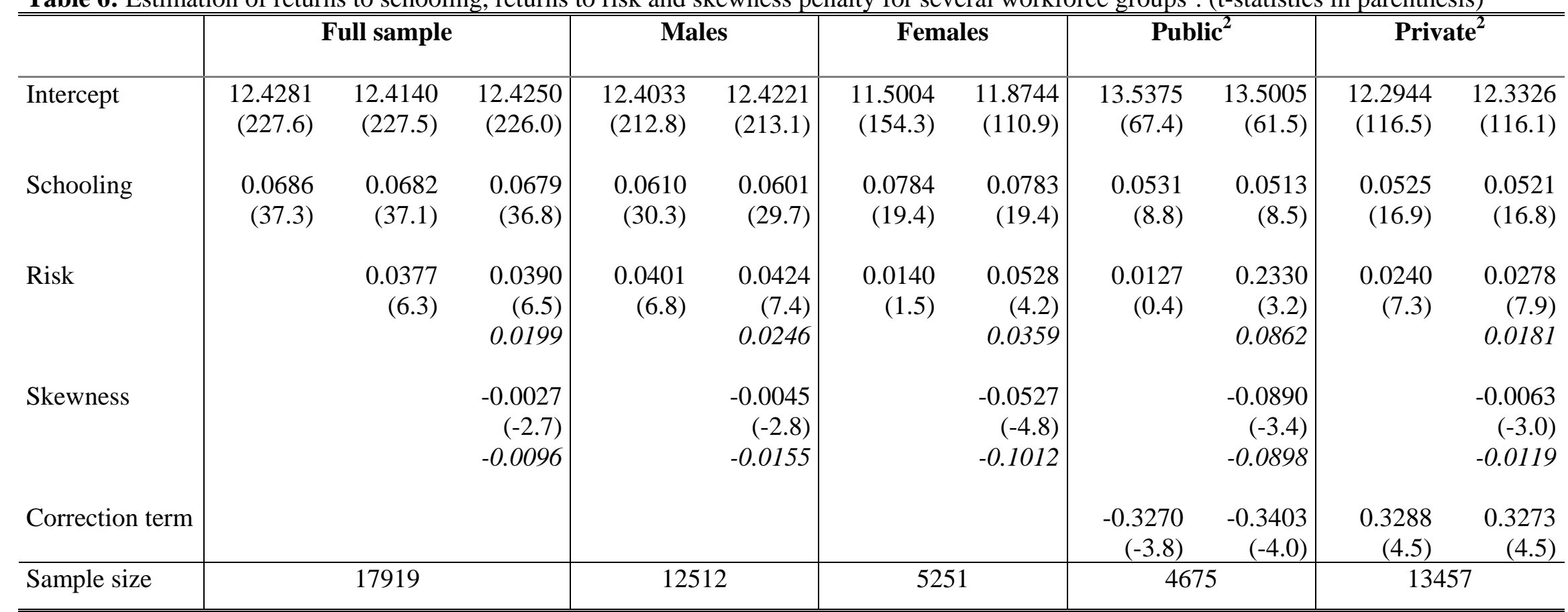

Notes: (1) Full model specification includes a cubic polynomial on years of experience, and dummy controls for gender, family status, geographical, industry and occupations

(2) Lee's selectivity correction 